\title{
ANALISIS YURIDIS TENTANG SENGKETA DALAM PROSPEKTIF KAJIAN HUKUM INTERNASIONAL
}

\author{
Ukas $^{1}$
}

\begin{abstract}
ABSTRAK
Sengketa dan atau konflik baik ia secara privat maupun publik akan berujung pada ketidak/kesepahaman para pihak atau subjek hukum lainnya. Dalam hubungan Internasional antar negara diperlukan keharmonisan diberbagai kegiatan, dan ini tidak akan tercapai jika para pihak tidak memiliki itikad baik dalam menyelesaikan sengketanya. Penyelesaian sengketa karenanya merupakan satu tahap penting dan menentukan. Dalam hal terjadinya sengketa, hukum internasional memainkan peranan yang juga esensial. Ia memberikan pedoman, aturan, dan cara atau metode bagaimana suatu sengketa dapat diselesaikan oleh para pihak secara damai. Upaya penyelesaian sengketa telah menjadi perhatian bagi masyarakat internasional, utamanya apabila menghdapi sengketa yang sifatnya bisnis yang melampaui batas-batas wilayah kedaulatan suatu negara. Penyelesaian sengketa secara damai merupakan cara yang telah diakui dan dipraktikkan sejak lama sampai saat ini. Suatu negara meskipun tunduk pada kewajiban penyesaian sengketa secara damai, ia tetap memiliki kewenangan menentukan caraa atau metode penyelesaian sengketanya. Kewajibannya tetap tunduk pada kesepakatan negara yang bersangkutan.
\end{abstract}

Kata Kunci: Sengketa, Penyelesaian Sengketa, Hukum Internasional.

\section{ABSTRACT}

Dispute and or its good conflict privat's ala and also public will tipped on to is not / kesepahaman the parties or subjek is another law. In International relationship required by congruity at various activity, and it won't be reached if the parties have no good faith in solve its dispute. Hence dispute working out constitutes one phase be of important and determining. In the event dispute, international law acts out that also essential. It gives guidance, order, and trick or method how a dispute gets to be solved by the parties in peace. Dispute working out effort have become attention for international society, it's main if menghdapi dispute that its character carries on business territorial intemperate one sovereign a state. Dispute working out in peace constitute trick already being admitted and dipraktikkan long since until now. A despite state bows the neck to to do bit penyesaian dispute in peace, it makes a abode to have kewenangan determines caraa or dispute working out method it. Its liabilities is constant bows the neck to pertinent state deal.

Keyword: Dispute; Dispute Working Out; International Law.

\footnotetext{
1 Dosen Program Studi Ilmu Hukum, Fakultas Sosial Dan Humaniora, Universitas Putera Batam, ukasibrahim@gmail.com 144
} 


\section{PENDAHULUAN}

Hubungan-hubungan Internasional yang diadakan antar-negara, negara dengan individu, atau negara dengan organisasi Internasional tidak selamanya terjalin dengan baik. Hubungan Internasional sering kali menimbulkan sengketa di antara mereka. Sengketa dapat diawali dari berbagai sumber potensi sengketa. Sumber potensi sengketa antar-negara dapat berupa perbatasan. Sumber daya alam, kerusakan lingkungan, perdagangan dan lain-lain, jika hal itu terjadi, hukum Internasional memainkan peranan yang tidak kecil dalam penyelesaiannya. Upaya-upaya penyelesaian telah menjadi perhatian yang cukup penting dimasyarakat Internasional sejak awal abad ke 20. Upaya-upaya ini ditunjukan untuk menciptakan hubungan antar-negara yang lebih baik berdasarkan prinsip perdamaian dan keamanan Internasional. ${ }^{2}$

Peran yang dimainkan hukum internasional dalam penyelesaian sengketa Internasional adalah memberikan cara bagaimana para pihak bersengketa menyelesaikan sengketanya menurut hukum Internasional. Dalam perkembangan awalnya, hukum Internasional mengenal 2 (dua) cara penyelesaian, yaitu cara penyelesaian sengketa secara damai dan perang (militer). Cara perang untuk menyelesaikan sengekta merupakan cara yang telah diakui dan dipraktekkan sejak lama, bahkan perang telah dijadikan sebagai alat untuk instrument dan kebijakan luar negeri. Adapun contoh yang dapat diberikan adalah Napoleon Bonaparte menggunakan perang untuk menguasai wilayah-wilayah di Eropa di abd XIX. ${ }^{3}$

Perang juga digunakan negara-negara untuk memaksakan hak-hak dan pemahaman mereka mengenai aturan-aturan hukum Internasional, bahkan telah menjadikan sebagai salah satu wujud dari tindakan negara yang berdaulat. Menteri Luar Negeri Amerika Serikat Robert Lansing pada tahun 1019 menyatakan bahwa : to declare war is one of the highest acts of sovereignty. ${ }^{4}$ Para sarjana menyadari bahwa praktek negara yang masih menggunakan kekerasan atau perang sengketa dewasa ini. Sebaliknya cara damai belum dipandang sebagai aturan yang dipatuhi dalam kehidupan atau hubungan antar-negara. Ajaran terkemuka Rumnia,on Diaconu, antara lain menyatakan bahwa : in manycases recourse to violence has been use and continues to be used in international relations, and the use of peaceful way and eans is nt yet the rule in international life, ${ }^{5}$ dalam perkembang kemudian dengan semakin berkembannya kekuatan meliter dan

\footnotetext{
${ }^{2}$ St. J. Macdonald and Douglas M. Johnson, The Structure and Prases of International Law, 1986, hal 1095

${ }^{3}$ Law : Achievment and Prospects, The Netherlands: Martinus Najho if Publishers, 1997, hlm. 520.

${ }^{4}$ M. Bedjaouidi kutip dalam International Law, 1947, hlm. 5.

${ }^{5}$ Ion Diaconu, Op. cit, hlm. 1095. 
perkembangan teknologi persenjataan pemusnah massal, masyarakat Internasional semakin mempercayai bahaya dari penggunaan perang. Arenanya mereka berupaya agar cara ini dihilangkan atau setidaknya dibatasi penggunaannya. ${ }^{6}$

Di samping itu, perlu dikemukaakan bahwa suatu sengketa bukanlah suatu sengketa menurut hukum Internasional, jika penyelesainnya tidak mempunyai akibat pada hubungan kedua belah pihak. Dalam sengketa The Northern Comeroons, Mahkamah Internasional dimana menyelesaikan suatu sengketa mengenai penafsiran suatu perjanjinan perwakilan (trusteeship) PBB yang sudah tidak berlaku. Dalam sengketa ini permohonan tidak menuntut apa-apa dari pihak lainnya, karenanya Mahkamah menolak untuk mengadili sengketa tersebut dengan mengemukakan bahwa dalam mengadili suatu sengketa, putusan mahkamah yang dikeluarkan haruslah mempunyai akibat praktis terhadap hubungan-hubungan hukum para pihak yang brsengketa.

Berdasarkan pendahuluan di atas maka rumusannya adalah

1. Bagaimana Peranan Hukum Internasional dalam menyelesaikan sengketa internasional?

2. Aturan hukum apa saja yang terkait dengan sengketa intrenasional itu?

3. Prinsip apa saja yang terkait dengan penyelesaian sengketa menurut hukum internasional?

Adapun Tujuan Penelitian dari penelitian ini antara lain:

1. Untuk mengetahui Peranan Hukum Internasional dalam menyelesaikan sengketa internasional

2. Untuk mengetahui Aturan hukum apa saja yang terkait dengan sengketa intrenasional itu

3. Untuk mengetahui Prinsip yang terkait dengan penyelesaian sengketa menurut hukum internasional

\section{METODE PENELITIAN}

Metode pendekatan yang penulis gunakan dalam penelitian ini adalah pendekatan hukum normatif atau penelitian yang mengkaji studi dokumen, yaitu menggunakan berbagai data seperti Peraturan-perundang-undangan dan juga dapat berupa pendapat para sarjana. Teknik pengumpulan data digunakan liberary research. Kegunaan penelitian ini secara teoritis memahami dan pemanfaatan dalam penyusunan berkas dalam penyelesaian sengketa yang sifatnya keperdatan secara internasional, agar para piahk yang terkait lebih mudah dan lebih efisien dalam memahami dan menyelesaikan sengketa secara Internasional.

\footnotetext{
${ }^{6}$ Jose Sette - Camara, Op. cit, hlm. 521.
} 


\section{HASIL PENELITIAN DAN PEMBAHASAN.}

1. Hukum dan Pengaturan Penyelesaian Sengketa dan Politik

Dalam studi hukum intermnasional publik, dikenal 2 (dua) macam sengketa internasional, yaitu sengketa hukum (legal ar judicial disputes) dan sengketa politik (political or nonjusticiable disputes). Sebetulnya tidak ada kreteria yang jelas dan diterima secara umum mengenai pengertian kedua istilah tersebut, yang kerap kali dipakai menjadi ukuran suatu sengketa dipandang sebagai sengekta hukum yang manakala sengketa tersebut bisa atau dapat diserahkan dan diselesiakan oleh pengadilan Internasional. Namun pandangan yang demikian sulit diterima. Sengketa-sengketa Internasional, secara teoritis pada pokoknya selalu dapat diselesaikan oleh pengadilan internasional. Sesulit apa pun suatu sengketa, sekalipun tidak ada pengaturannya, suatu pengadilan internasional tampakanya dapat memutuskanya dengan bergantung kepada prinsip kepatutan dan kelayakan (ex aequo et bono). Pokoknya, ada banyak sengketa yang dapat diselesaaikan oleh pengadilan Internasional tetapi salah satu atau kedua negara negara menyerahkannya kepada pengadilan, pengadilan menjadi tidak berwenang mengadilinya. Dalam hal ini, yang menjadi dasar hukum bagi pengadilan untuk melaksanakan yurisdiksinya adalah kesepakatan para pihak yang bersengketa.

Lebih lanjut penulis memaparkan beberapa pendapat pakar hukum Internasional dalam penyelesaian sengketa Internasional yang kira dapat dijadikan anasir pendapat atau minimal bahan acuan dan atau refrensi tambahan dalam penyelesaian sengketa menurut hukum Internasional antara lain : 
Menurut pendapat Prof. Wolfgang Friedmann mengemukakan bahwa: meskipun sulit untuk membedakan kedua pengertian tersebut, namun perbedaaannya dapat terlihat pada konsepsi sengketanya. Konsepsi sengketa hukum memuat hal-hal berikut :

a. Sengketa hukum adalah perselisihan antar negara yang mampu diselesaikan oleh pengadilan dengan menerapkan aturan-aturan hukum yang ada atau yang sudah pasti.

b. Sengketa hukum adalah sengeketa yang sifatnya mempengaruhi kepentingan vital negara, seperti integritas wilayah dan kehormatan atau kepentingan lainnya dari suatu negara.

c. Sengketa order Armed Action penerapan hukum Internasional yang ada, cukup untuk menghasilkan suatu putusan yang sesuai dengan keadilan antara-nergara dengan perkembangan progresif hubungan internasional.

Sengketa hukum adalah yang berkaitan dengan persengketaan hak-hak hukum yang dilakukan melalui tuntutan yang menghendaki suatu perubahan atas suatu hukum yang telah ada. Pandangan di atas diikuti oleh International Court of Justice (ICJ). Dalam sengketa the border and Transborders Armed Actions (1998). ICJ menyatakan yang dimaksud dengan sengketa hukum adalah a dispute capable of being sttled by application of principles and rukles of international law. ${ }^{7}$

Menurut Waldock, pendapat kedua dikemukan oleh para sarjana dan ahli hukum International dari Inggris yang membentuk suatu kelompok studi mengenai penyelesaian sengketa tahun 1963. Kelompok studi yang diketahui oleh Sir Humprey Waldock ini menerbitkan laporannya yang sampai sekarang masih dipakai sebagai sumber penting untuk studi tentang penyelesaian sengketa Internasional. Menurut kelompok studi ini penentuan suatu sengketa sebagai salah satu sengketa hukum atau politik bergantung sepenuhnya kepada para pihak yang bersangkutan. Jika para pihak menentukan sengketanya sebagai sengketa hukum maka sengketa tersebut adalah sengketa hukum sebakliknya jika sengketa tersebut menurut para pihak membutuhkan patokan tertentu yang tidak ada dalam hukum internasional, misalnya soal perlucutan senjata maka sengketa tersebut adalah sengketa politik.

Pendapat jalan Tengah (Oppenhem Kelsen). Menuurut pendapat tersebut bahwa tidak ada pembenaran ilmiah serta tidak ada dasar kriteria objektif yang mendasari pembedaan, antara sengketa politik dan hukum. Menurut mereka, setiap sengketa memiliki aspek politis dan

${ }^{7}$ Martin Dixon, Textbook on International Law, London BlaA8tone 4th ed: 2000, hal 272 
hukumnya sengketa tersebut biasanya terkait antar-negara yang berdaulat. Mungkin saja dalam sengketa yang dianggap sebagai sengketa hukum terkandung kepentingan politis yang tinggi dari negara yang bersangkutan.

Di samping itu ada istilah sengketa hukum dan politik, ada istilah lain yang sama-sama tunduk pada penyelesaian sengketa secara damai. Istilah tersebut adalah situasi (situation). Pasal lainnya adalah Pasal 34 Piagam PBB: The urity Council may investigate any dispute, orany situation which might lead to international friction or give rese to a dispute. Istilah situasi tersebut haruslah diartikan secara luas. Situasi tersebut menurut para pakar hukum Internasional adalah sengketa bukan merupakan sengketa sebenarnya yang sedang berlangung antar-negara. Kata situasi tersebut termuat dalam kaitannya dengan fungsi PBB dan/atau tugas Dewan Keamanan. Ia tidak diletakan di bawah suatu organisasi atau badan yang memiliki konpetensi hukum (pengadilan). Kata situasi "atau De jure Bell ac Pacis" (1625). Perang 30 tahun di Eropa yang terakhir dengan ditanda tangani perjanjian perdamaian di kota Munster (perjanjian Westphalia) tahun 1648 yang disusul kemudian dengan Perang Dunia I dan Perang Dunia II merupakan salah satu contoh sengketa yang memunculkan hukum Intrnasional yang dikenal dewasa ini. Menurut tokoh di atas pendekatan yang diambil oleh Waldock "lebih tepat" jika timbul sengekta antara dua negara, bentuk atau jenis sengketa yang bersangkutan ditentukan sepenuhnya oleh para pihak. Suatu sengketa hukum, bisa merupakan penetapan garis batas wilayah. Pelanggaran hak-hak istimewa diplomatik, sengketa hak-hak dan kewajiban dalam perdagangan, dan lain-lain. Pastinya sengketa demikian sedikit banyak mempengaruhi hubungan (baik) kedua negara. Bagaimana kedua negara memandang sengketa tersebut, akhirnya menjadi faktor penentu apakah sengketa yang bersangkutan, sengketa hukum atau politik.

Lebih lanjut penyelesaian sengketa dalam Piagam PBB dan Aturan Turunannya:

\section{Piagam PBB}

Salah satu tujuan didirikannya PBB adalah Untuk memelihara perdamaian dan keamanan internasional. Hal ini tampak dalam Pasal 1 ayat (1) Piagam PBB : To maintain International peace andsecuruty, $d$ to tht end: to take effective collctive measures fo prevention and removal of threats to the peace, and to bring about by peaceful means, and in conformity with the principles of justice and international la, adjustment or settlement of international disputes or situation which might lead to a breach of peace. 
Tersirat dalam ketentuan pasal tersebut bahwa fungsi dari badan dunia ini dan negaranegara anggotanya yaitu untuk bersama-sama menciptakan dan mendorong penyelesaian sengketa internasional. Khusus terhadap negara-negara anggotanya, Pasal 2 ayat (3) Piagam memberikan pengaturan lebih lanjut guna melaksanakan dan mencapai tujuan di atas. Pasal ini mewajibkan semua negara anggotanya untuk menempuh cara-cara menyelesaian sengketa secara damai. (Pasal 2 ayat (3). Kewajiban lainnya yang terdapat dalam Piagam tercantum dalam Pasal 2 ayat (4). Pasal ini menyatakan bahwa hubungan internasional, semua negara harus menahan diri dari penggunaan cara-cara kekerasan penggunaan senjata terhadap negara lain atau cara-cara yang tidak sesuai dengan tujuan PBB Pasal 2 ayat (4). Dua kewajiban yang tertuang dalam kedua ayat di atas, yaitu kewajiban menahan diri menggunakan cara kekerasan atau ancaman kekerasan. Kedua kewajiban tersdebut harus dipandang berdiri sendiri. Piagam PBB menyatakan kewajiban negara-negara berdaskan Pasal 2 ayat (3) untuk menahan diri dalam penggunann kekerasan atau ancaman kekerasan sebagaimana diwajibkan dalam Pasal 2 ayat (4), dengan kata lain, kewajiban terdapat dalam ayat ( 3 bukanlah merupakan akibat atau konsekuensi logis dari kewajiban yang terdapat dalam ayat (4). Sebaliknya, Piagam menetapkan kewajiban terhadap anggota-anggotanya untuk menyelesaikan sengketa dengan cara damai sebagai suatu aturan yang berdiri sendiri, dan sebagai aturan dasar (fundamental). ${ }^{8}$ Kewajiban dalam Pasal 2 ayat (3) tidak dipandang sebagai suatu kewajiban yang pasif. Kewajiban tersebut terpenuhi manakala negara yang bersangkutan menahan dirinya untuk melakukan kekerasan atau ancaman kekerasan atau ancaman kekerasan.

Menurut Komisi Hukum International, prinsip larangan atau penggunaan kekerasan sebagaimana tersurat dalam Piagam sudah merupakan hukum internasional umum yang penerapannya sudah universal. Komentar panting ini menyatakan : The principles regarding the the threat or use of fore laid down in the charter are...rules of general internasional law which areof today universal application. ${ }^{9}$

\footnotetext{
${ }^{8}$ Resolusi Majlis Umum PBB No. 1815 (XVII) dalam Pembentukan Panitia Khusus, The Special Committee on Principles of International Law

${ }^{9}$ David Davies Memorial of International Studies, Op.cit, hlm. 7
} 


\section{Resolusi-Resolusi PBB}

Penyelesaian sengketa demikian diperkuat kembali dengan resolusi Majelis Umum (MU PBB No. XXV) 1970 yang intinya adalah memperhitugkan hubungan-hubungan yang baik, Hubungan persahabatan dan kerjasama di negara-negara sesuai dengan Piagam PBB) atau Friendly Relations Declaration. Resolusi MU PBB No.2625/XXV yang diperkuat dgan resolusi MU No. 44/21/1989. Resolusi ini negara-negara untuk memajukan perdamaian dan keamanan serta kerja sama Internasional sesuai dengan Piagam PBB.

Uraian di atas tampak bahwa cara penyelesaian sengketa tersebut sudah menjadi aturan-aturan yang perlu dan harus digunakan atau dipertimbangkan. Konvensi Den Haag sebagai contoh yang akan penulis berikan mengenai penyelesaian sengketa Internasional secara damai tahun 1899 dimana konvensi ini memuat ketentuan mengenai jasa-jasa baik, mediasi, Komisi penyelidikan Internasional (international commission of inquiry), dan arbitrase,. Konvensi ini sampai sekarang masih berlaku dan mengikat lebih 60 negara. Konvensi Den Haag 1899 ini diubah pada konfensi perdamaian Den Haag pada tahun 1907. Perubahan yang menonjol terjadi pada komisi penyelidikan dan prosedur arbitrase. $^{10}$

Berdasarkan Pasal 33 Piagam dan Resolusi tersebut, pada pokoknya cara penyelesaian sengketa secara damai dibagi dalam 2 (dua) kelompok yaitu :

a. Penyelesaian sengketa secara deplomatik, yaitu negosisisi, penyelidikan, mediasi dan konsiliasi, di samping cara-cara lainnya yang masih dimungkinkan dipilih atau diinginkan oleh para pihak.

b. Cara penyelesaian secara hukum, yaitu arbitrse dan pengadilan, kalimat terakhir dari Pasal 33 Piagam PBB, yaitu penyerahan sengketa kebadan-badan regional atau caracara lainnya yang menjadi pilihan para pihak. Biasanya mengacu pada badan-badan peradilan yang terdapat dan diatur oleh berbagai organisasi internasional, baik yang sifatnya global maupun regional.

\footnotetext{
${ }^{10}$ Louis B. Sohn dan J.G. Merrills, International Dispute Settlements, Grotius Publicsation, Cetakan ke 2, 1991, hlm 2
} 
Sengketa dijajaran hukum internasional dan atau sengketa politik dalam kajian Hukum Internasional hal tersebut secara garis besarnya yaitu sengketa politik dan kedua sengketa hukum. Menurut optional clause" dari Pasal 33 Satatuta, Yurisdiksi Mahkamah untuk menagani sengketa hukum dibatasi pada tempat kategori antara lain penafsiran, setiap masalah hukum Internasional dan adanya keadaan yang memerlukan pemulihan akibat pelanggran itu.

Dapat dikualifikasikan sebagi sengketa politik bila, satu negara memandang bahwa hukum internasional cakupan memadai untuk menyelesaikan sengketa Internasional tidak cukup. Apabila penyelesaian sengketa melalui hukum Intrenasioanl bertentangan dengan moral internasional, kelemahah hukum dari kasuusnya baik secara hukum ataupun secara fakta. Para pakar hukum ternasional membedakan sengketa hukum internasional dengan sengketa politik, Menurut Oppenheim-lauterpacht mendasarkan klaimnya berdasarkan hukum internasioanl, sedangkan perbedaannya lainnya lebih bersifat politik atau konflik kepentingan, dan mereka menggunakan istilah legal dispute akan tetapi justiciable untuk sengketa political disputes. Memecahkan sengkea hukum dan politik bahwa dengan menatakan bahwa dalam setiapsengketa atau konflik Internasional yang terjadi maka dapat direduksi menjadi sengketa hukum. Caranya adalah dengan membawa sengketa tersebut ke dalam Pengadilan atau arbitrase, tentunya berdasarkan kehendak para pihak yang bersengketa. Berkaca pada pendapat Friedmann dapat dipahami bahwa pada konsepsi - konsepsinya bahwa sengketa dan aatu perselisihan itu mampu diselesaikan oleh para piha. Apakah melalui pengadilan atau arbitrase dll. Kedua bahwa sengketa itu tentu mempengaruhi kepentingan vital negaranseperti intehritas wilayah dan kehormatan atau kepentinganlainnya.

Ketiga adalah sengketa hukum adalah sengketa dimana penerapan hukum Internasional yang ada cukup menghasikkan suatu putusan yang sesuai dengan keadaan antarnegara dengan perkembangan progresif hubungan Internasional. Lebih lanjut sengketa hukum yang dilakukan atau sengekta yang berkaitan dengan perseorangandimana hak-hak mereka diperhatikan dn dengan melalui tuntutan sesuai perubaghan dan tuntutan hukum yang ada. Intinya sengketa ini diserahkan kepada para pihak untuk mennetukan sengketanya dan jalan terbaik untuk para pihak agar sengketa ini 
selesai.

2. Peranan Hukum Internasional (Konfrensi Den Haag 1899 dan 1907)

Dewasa ini hukum internional memiliki peranan besar menyelesaikan sengketa internasional:

a. Pada prinsipya hukum internasional berupaya agar hubungan antar negara terjalin lewat ikatan persahabtan (friendly relation among states) dan tidak mengharapkan adanya persengketaan.

b. Hukum internasional memberikan aturan pokok kepada negara-nega yang bersengketa untuk menyelesaikan sengketanya

c. Hukum internasinal memberikan pilihan yang besar kepada para pihak tentang cara, prosedur atau upaya yang seyogyanya ditempuh untuk menyelesaikan sengketanya

d. Hukum internasional modern semata-mata mengatur cara penyelesaian sengketanya secara damai, apakah itu sifatnya antarnegara atau dengan subjek hukum Intenasional lainnya. Hukum internasional tidak menganjurkan sama sekali cara kekerasan atau peperangan. ${ }^{11}$

Perkembangan hukum International dalam mengatur tata cara cara penyelesaian sengketa secara damai ini secara formal pertama kali lahir sejak diselenggarakannya The Hague Peace Confrensi Perdamaian Den Haag) tahun 1899 dan 1907. Konfrensi perdamaian ini menghasilkan the Convention on the Pacific Settlement of International Disputes tahun 1907. Konfrensi Perdamaian Den Haag yang penting ini bermula dari inisiatif Tsar Rusia Nicholas II Pada tahun 1899. Beliau mengusulkan perlunya diselenggarakan suatu konfrensi yang bertujuan untuk mengurangi jumlah persenjataan atau setidaknya membahas kemungkinan mengakhiri perkembangan progresif persenjataan. Usulan tersebut disambut baik oleh Ratu Belanda. Mereka mengundang negara-negara lainnya untuk membahas usulan penyelenggaraan suatu konfrensi internasional. Undangan ini disambut hangat dengan dilangsungkannya Konfrensi Den Haag tahun 1899. Peserta konferensi umumnya adalah negara-negara Eropa, Amrika Serikat dan Jepang.

\footnotetext{
${ }^{11}$ Louis B. Sohn, Op. Cit, Epil 1, hlm. 155.
} 
Konfrensi perdamaian Den Haag tahun 1899 dan 1907 ini memiliki dua arti penting yaitu:

a. Konferensi memberikan sumbangan penting bagi hukum perang (sekarang hukum Internasional)

b. Konfrensi memberikan sumbangan penting bagi aturan-aturan penyelesaian sengketa secara damai antarnegara. ${ }^{12}$

Berdasarkan dua konvnsi the Haque megenai penyelesaian sengketa internasional ini, para (anggota) berupaya secara maksimal untuk menyelesaikan sengketa secara damai. Untuk maksud itu, sepanjang keadaan masih memungkinkan atau mengizinkan, para pihak sepakat untuk menyerahkan sengketa mereka kepada jasa-jasa baik, mediasi atau komisi penyelidik untuk menyelesaikan sengketa mereka (cara diplomatik). Apabila cara diplomatik ini gagal maka penyerahan sengketa kepada arbitrase atau diperkenankan. Berdasarkan Pasal 38 Konvensi Den Haag 1907, penyerahan sengketa kepada arbitrase sifatnya tidak memaksa karena penyerahan kepada badan ini baru akan dilakukan apabilla keadaannya memungkinkan. ${ }^{13}$

Hasil dari konvensi di atas syangnya tidak memberikan suatu kewajiban kepada negara peserta untuk menyelesaikan sengketanya melalui cara-cara damai. Menurut Ion Diaconu, hasil konvnsi bersifat rekomendatif semata. Perkembangannya kemudian diikuti dengan disahkannya perjanjian internasional brikut antara lain :

a. The Convention for the Pacific Convenant of the League of Nations tahun 1919

b. The state of the Permanent Court of International Justice (Statuta Mahkamah Internasional Permanen) tahun 1921

c. The General Treaty for the Renunciation of War tahun 1928

d. The General Act for the Pacific Settlement of International Disputes tahun 1928.

e. Piagam PBB dan Statuta Mahkamah Internasional (1945). ${ }^{14}$

\footnotetext{
12 Hans Kelsen, The Law of The Nations, 1951, hal 73

${ }^{13}$ Konvesi Den Haag 1907

${ }^{14}$ Piagam PBB dan Statute Mahkamah Internasional 1945
} 
f. Deklarasi Bandung (Bandung Declaration) 1955, yang antara lain menyatakan:

Settlement of all disputes by peaceful means such as negotiation.

Manila Declaration atau Deklarasi Manila merupakan hasil inisiatif dan upaya majelis umum PBB dalam menggagalkan penghormatan terhadap penggunaan cara penyelesaian sengketa secara damai. Deklarasi Manila antara lain menyatakan :

a. adalah kewajiban negara-negara yang bersengketa untuk mencari jalan dengan itikad baik dan semagat kerja sama, menyelesaikan sengketa Internasional mereka secepat mungkin dan seadil-adilnya.

b. negara-negara harus juga mempertimbangkan peran penting yang dapat dimainkan oleh Majelis Umum, Dewan Keamanan, Mahkamah Internasional, dan Sekretaris Jenderal PBB dalam menyelesaikan suatu sengketa

c. deklarasi menyatakan pula adanya berbagai cara yang dapat dimintakan oleh organ-organ PBB untuk membantu para pihak mencapai suatu penyelesaian sengketa mereka.

d. Pada tahun 1988, Majelis Umum memutuskan untuk menambah deklarasi Manila dengan deklarasi lainnya, yaitu deklarasi 1988, dimana deklarasi ini menetapkan secara khusus langkah-langka yang harus diambil Dewan Keamanan untuk mencegah suatu sengketa menjadi ancaman tarerhadap perdamaian dan memajukan penggunaan penyelesaian sengketa secara damai. ${ }^{15}$

Perkembangan penting dalam hukum internasional dalam topik ini adalah ditetapkannya tahun 1990-1999 sebagai Deklasrasi Hukum Internasional PBB oleh Majelis Umum pada tahun 1988. Dalam salah satu pernyataannya, Majelis Umum menyatkan bahwa tujuan utama dari dekade hukum internasional ini adalah untuk memajukan cara atau metode penyelesaian sengketa antar negar, termasuk penyerahan sengketa dan penghormatan kepada Mahkamah Internasional. Dewasa ini hukum Internasional telah menetapkan kewajiban minimum kepada semua negara (anggota PBB) untuk menyelesaikan sengketa internasionalnya secara damai. Ketentuan ini tersurut khususnya dalam Pasal 1, 2 dan 33 Piagam PBB

\footnotetext{
${ }^{15}$ Ibid. Piagam PBB
} 
Menurut Levy kewajiban di atas sifatnya sudah menjadi hukm internasional universal. Kewajiban ini tersebut mensyaratkan bahwa negara-negara harus menyelesaikan sengketanya denga cara-cara damai sedemikian rupa sehingga perdamainan dan keamanan Internasional dan keadilan tidak terancam. ${ }^{16}$ Suatu negara meskipun tunduk pada kewajiban penyelesaian sengketa secara damai, ia tetap memiliki kewenangan penuh untuk menentukan cara-cara atau metode penyelesaian sengketanya. Kewajiban tersebut tetap tunduk pada kesepakatan (consensus) negara yang bersangkutan.

3. Komisi Hukum International, dan Prinsip yang Terkait Sengketa Internasional.

Menurut Komisi Hukum Internasional dan Prinsip larangan atau penggunaan kekerasan sebagaimana tersurat dalam piagam sudah merupakan hukum Internasional umum yang penerapannya sudah universal. Komentar panting ini menyatakan : The principles regarding the the threat or use of fore laid down in the charter are...rules of general internasional law which areof today universal application. ${ }^{17}$

Resolusi-Resolusi PBB

Penyelesaian sengketa demikian iperkuat kembali dengan reolusi Majlis Umum (MU PBB No. XXV) 1970 yang intinya adalah memperhitugkanhubungan-hubunan yang baik, Hubungan persahabatan dan kerjasama di negara-negara sesuai dengan Piagam PBB) atau Friendly Relations Declaration. Resolusi MU PBB No.2625/XXV yang diperkuat dengan resolusi MU No. 44/21/1989. Resolusi ini meoron negara-negara untuk memajukan perdamaian dan keamanan serta kerja sama Internasional dalamsua aspek sesuai dengan Piagam PBB. Dalam uraian di atas tampak bahwa cara penyelesaian sengketa tersbut sudah menjadi aturan aturan yang perlu dan harus digunakan atau dipertimbangkan. Konvensi Den Haag mengenai penyelesaian sengeta Internasional secara damai tahun 1899 sebagai contoh lainnya konvensi ini memuat ketetntuan mengenai jasa-jasa baik, mediasi, komisi penyelidikan Internasional (International commission of inquiry), dan arbitrase. Konvensi ini sampai sekarang masih berlaku dan mengikat lebih 60 negara. Konvensi Den Haag 1899 ini diubah pada konfensi perdamaian Den Haag kedua tahun 1907.

\footnotetext{
${ }^{16}$ Wernes Levy, Contemporary International Law A. Concise Introduction, Westview 2 ed 1991 hlm. 276.

${ }^{17}$ Wernes Levy , Id. at, hlm 278.
} 
Perubahan yang menonjol terjadi pada komisi penyelidikan dan prosedur arbitrase. Berdasarkan Pasal 33 piagam dan resolusi tersebut, pada pokoknya cara penyelesaian sengketa secara damai dibagi dalam dua kelompok yaitu:

a. Penyelesaian sengketa secara deplomatik, yaitu negosisisi, penyelidikan, mediasi dan konsiliasi, di samping cara-cara lainnya yang masih dimungkinkan dipilih atau diinginkan oleh para pihak.

b. Cara penyelesaian secara hukum, yaitu arbitrse dan pengadilan. Kalimat terakhir dari Pasal 33 Piagam PBB, yaitu penyerahan sengeta ke badan-badan regional atau cara-cara lainnya yang menjadi pilihan para pihak. Biasanya mengacu pada badan-badan peradilan yang terdapat dan diatur oleh berbagai organisasi internasional, baik yang sifatnya global maupun regional.

Sengketa hukum Internasional dan atau sengketa poltik dalam kajian Hukum internasionall hal tersebut secara garis besarnya yaitu sengketa golongan sengketa olitik dan kedua sengketa hukum. Menurut optional clause" dari Pasal 33 Statuta, yurisdiksi mahkamah untuk menagani sengketa hukum dibatasi pada empat kategori antara lain penafsiran, setiap masalah hukum Internasional dan adanya keadaan yang memerlukan pemulihan akibat pelanggran itu.

Dapat dikualifikasikan sebagi sengketa politik apabila, pertama, satu negara memandang bahwa hukum Internasional baik cakupan memadai untuk menyelesaikan sengketa Internasional tidak cukup. Penyelesaian sengketa melalui hukum Intrenasioanl bertentangan dengan moral Internasional, kelemahah hukum dari kasuusnya baik secara hukum ataupun secara fakta. Para pakar hukum ternasional membedakan sengketa hukum Internasional dengan sengketa politik, Menurut Oppenheim-lauterpacht mendasarkan klaimnya berdasarkan hukum Internasional, sedangkan perbedaannya lainnya lebih bersifat politik atau konflik kepentingan. Dan mereka menggunakan istilah legal dispute akan tetapi justiciable untuk sengketa political disputes.

Memecahkan sengka hukum dan politik bahwa dengan menyatakan bahwa dalam setiap sengketa atau konflik Intrnasional yang terjadi maka dapat direduksi menjadi sengketa hukum. Caranya adalah dengan membawa sengketa tersebut ke dalam pengadilan atau 
arbitrase, tentunya berdasarkan kehendak para pihak yang bersengketa. Berkaca pada pendapat Friedmann dapat dipahami bahwa pada konsepsi - onsepsinya bahwa sengketa dan aatu perselisihan itu mampu diselesaikan oleh para piha. Apakah melalui pengadilan atau arbitrase dll.

Kedua bahwa sengketa itu tentu mempengaruhi kepentingan vital negara seperti intehritas wilayah dan kehormatan atau kepentinganlainnya.

Ketiga adalah sengketa hukum adalah sengketa dimana penerapan hukum Internasional yang ada cukup menghasilkan suatu putusan yang sesuai dengan keadaan antarnegara dengan perkembangan progresif hubungan Internasional. Lebih lanjut sengketa hukum yang dilakukan atau sengekta yang berkaitan dengan perseorangan dimana hak-hak mereka diperhatikan dan dengan melalui tuntutan sesuai perubahan dan tuntutan hukum yang ada.

Sengketa ini diserahkan kepada para pihak untuk mennetukan sengketanya dan jalan terbaik untuk para pihak agar sengketa ini selesai.

4. Prinsip Hukum Dalam Penyelesaian Sengketa Secara Damai.

Dari berbagai aturan hukum internasional di atas, termasuk dan trutama Deklarasi Manila, dapat dikmukakan di sini prinsip-prinsip mengenai penyelesaian sengketa Internasional, sebagai berikut:

a. Prinsip Itikad Baik. Prinsip ini dapat dikatakan sesuai prinsip fundamental dan paling sentral dalam penyelesaian sengketa antar negara. Prinsip ini mensyaratkan dan mewajibkan adanya itikad baik dari pihak dalam menyelesaikan sengketanya. Tidak heran apabila prinsip ini dicantumkan sebagai prinsip pertama (awal) yang termuat dalam Manila rising. Persyaratan itikad baik juga ditempatkan sebagai syarat utama. Pasal 13 Bali Concord menyatakan The high contraction parties shall have the determnination and good faith to prevent disputes from arising.

Dalam penyelesaian sengketa, prinsip ini tercantum di dalam dua tahap. Pertama, prinsip itikad baikdisyaratkan untuk mencengah timbulnya sengketa yang dapat mempengaruhi hubungan baik antarnegara. Kedua, prinsip ini disyaratkan hurus ada ketika para pihak menyatakan sengketanya melalaui cara-cara penyelesaian sengketa . 
b. Prinsip Larangan Penggunaan Kekerasan dan Penyelesaian sengketa. Prinsip ini sangat sentral dan penting, Prinsip inilah yang melarang para pihak untuk menyelesaikan sengketanya. Engan menggunakan senjata (kekerasan). Prinsip ini termuat dalord dan pram Pasal 13 Bali Concord dan prebule.

c. Prisip Kebebasan memilih cara-cara penyelesaian sengketa. Prinsip penting lainnya adalah prinsip dimana para pihak memiliki kebebasan penuh untuk menentukan dan memilih cara atau mekanisme bagaimana sengketanya diselesaikan.

d. Prinsip Kebebasan Memilih hukum yang akan diteraokan terhadap Terhadap Pokok Sengketa. Prinsip ini sifatnya fundamental selanjutnya sangat penting adalah prinsip kekebasan para pihak untuk menekan sendiri hukum apa yang akan diterapkan Dalam sengketa antar negara, merupakan hal yang lazim bagi Pengadilan internasional, misalnya mahkamah Internasional, untuk menerapkan hukum hukum Inteternasional ini tidak dinyatakan secara tegas oleh para pihak.

e. Prinsip Kesepaakatan Para Pihak yang bersengketata (Konsensus). Prinsip kesepakatan para pihak merupakan prinsip fiundamental dalam penyelesaian sengketa Internasional . Prinsip - Prinsip inilah yang menjadi dasar bagi pelaksanaan prinsip ke-3 dan 4 di atas.

Disamping prinsip-prinsip di atas. Office of thel egal Affairs PBB memuat prinsipprinsip lainnya yang intinya adalah prinsip laarangan intervesi, persamaan hak dan penentuan nasib sendiri, kemerdekaan dan hukum internasional yang semata-mata merupakan kelanjutan dari prinsip tentang kedaulatan, kemerdekaan, integritas wilayah suatu negaranegara.

\section{SIMPULAN DAN SARAN}

\subsection{Simpulan}

1. Salah satu pengaturan yang tekait dalam penyelesain sengketa intrernasional adalah pengaturan yang diatur dalam Piagam, Resolusi-resolusi yang intinya penyelesaian secara diplomatic dan atau penyelesaian secara hukum.

2. Peranan hukum yang terkait dalam penyelesaian sengketa internasional adalah menganjurkan penyelesaian secara damai dengan menentukan dan atau menetapkan kewajiban minimum kepada semua negara untuk menyelesaikan sengketa secara damai. 
3. Prinsip-Prinsip hukum yang terkait dalam penyelesaian sengketa internasional antara lain adalah prinsip Good Faith, prinsip menggunakan kekerasan, dan principle of freec choice of means serta prinsip consensus.

\subsection{Saran-Saran}

1. Dalam penyelesaian sengketa Internasional diharapkan para pihak selain memahami hukum Internasional juga memahami hukum nasional para pihak.

2. Memahami peranan hukum internasional bukan saja memahami teori tetapi juga memahami aplikasinya.

3. Diharapkan memahami prinsip-prinsip hukum lebih sempurna dalam memahami sengketa internasional.

\section{DAFTAR PUSTAKA}

\section{Buku, Jurnal Dan Makalah}

Ion Diaconu, Peaceful Settlement of Disputes Between States : History and Prospects, Dalam R.St.J.Mac Donald., 1986

Jose Sette-Gamara, Methods of Obligatpry settlement of Disputes (International Law) : Achievements and Prospects. 1997

Lauterpacht. Recognition in international Law, 1997

ICI Rep 6g termuat Dalam Martin Dixon, Text Book On Intenational Law, London : Blackstone 4 ed, 2000

Resolusi Majelis Umum PBB No. 1815 (XVII)

Huala Adolf dalam bukunya Hukum Penyelesaian Sengketa, dan Penyelesaian sengketa melalui cara peperaangan. hal tersebut seuai dengan Ceorg schwar Zenberger, International Law, Vol: 1968

David J. Bederman, The Hague Peace Conference of 1899 and 1907, Dalam Mark W.Janis (ed), International Courts for Twenty First Century. Dordrecht : Martinus Nijhoff, 1992

Werner Levy, Conteporary International Law A. Concise Introduction, Westview. 2 ed 1991 